\title{
INFLUENCE OF IRRIGATION AND POTASSIUM FERTILIZATION ON THE PRODUCTION AND QUALITY OF BANANA FRUIT IN BRASÍLIA
}

\author{
Douglas Ramos Lorena ${ }^{1}$, Cícero Lopes da Silva², José Ricardo Peixoto ${ }^{3}$, Gustavo Pires de Oliveira ${ }^{4}$, Gervásio \\ Fernando Alves Rios ${ }^{5}$
}

\begin{abstract}
The present work aimed to evaluate quantitative and qualitative aspects of the initial productivity of the 'BRS Tropical' banana under different levels of potassium fertilization and irrigation volumes. The tests were arranged in four randomized blocks, which were consisted of a $5 \times 5$ factorial design, in slit-plot design. These plots were formed by five different applied volumes of water in liters per pit (1090 - 2177-4300-6540 - 8720), which were equivalent to the amount of irrigation of water of $121 \mathrm{~mm}, 242 \mathrm{~mm}, 478 \mathrm{~mm}, 727 \mathrm{~mm}$ and $969 \mathrm{~mm}$ regarding the range of $9 \mathrm{~m}^{2}$ for each pit. The subplots were formed by five levels of potassium in $\mathrm{Kg}_{\text {.ha }}{ }^{-1}(0-167-334-500-667)$. Both volumes of irrigation and levels of potassium were provided during the years of 2013 and 2014. The variables analyzed were for productivity, number of bunches per ha, number of hands per bunches, number of bananas per bunch, number of bananas per hand, average fruit weight, average length and diameter of the banana, the ratio between diameter and length and average pulp consistency. The doses of $500 \mathrm{Kg}^{-h a^{-1}}$ of $\mathrm{K}_{2} \mathrm{O}$ and 6,540 liters of water per pit provided the highest productivity $\left(11,752 \mathrm{Kg} \cdot \mathrm{ha}^{-1}\right)$. The volumes of water were only statistically significant to the mass of fruit, as well as its length and diameter. The potassium application required caution, because excessive doses of potassium are harmful to productivity and quality of the fruit.
\end{abstract}

Keywords: chilling occurrence, Musa spp., optimum of the variables studied, productivity observed

\section{RESUMO}

\section{PRODUÇÃO E QUALIDADE DE FRUTOS DE BANANEIRA INFLUENCIADOS POR IRRIGAÇÃO E ADUBAÇÃO POTÁSSICA EM BRASÍLIA}

Avaliou-se aspectos quantitativos e qualitativos da produtividade, da bananeira 'BRS Tropical' sob diferentes níveis de adubação potássica e volumes de irrigação. O presente experimento foi disposto em quatro blocos inteiramente casualizados, consistindo nas repetições, em um esquema fatorial 5x5, em parcelas subdivididas. As parcelas foram formadas por cinco volumes de irrigação em litros por cova, $(1090-2177$ - $4300-6540-8720)$, correspondente às lâminas de $121 \mathrm{~mm}, 242 \mathrm{~mm}, 478 \mathrm{~mm}, 727 \mathrm{~mm}$ e $969 \mathrm{~mm}$ em função da área ocupada por cada cova; 9 m². As subparcelas pelos cinco níveis de potássio em kg.ha-1 $(0-167$ - $334-500$ - 667). Tanto os volumes de irrigação quanto os níveis de potássio foram fornecidas durante os anos de 2013 e 2014. As observações analisadas foram produtividade, número total de cachos por ha, número de pencas por cacho, número de bananas por cacho, número de bananas por penca, peso médio do fruto, comprimento, diâmetro médio do fruto, relação entre comprimento e diâmetro e a firmeza média da polpa. A maior produtividade observada foi $11.752 \mathrm{Kg}$.ha ${ }^{-1}$, correspondente a 500 $\mathrm{Kg}_{\mathrm{h}} \mathrm{ha}^{-1}$ de $\mathrm{K}_{2} \mathrm{O}$ e 6.540 litros de água por cova. Os volumes de irrigação foram significativos para massa do fruto, comprimento e diâmetro, no entanto, não foram para as demais variáveis estudadas. Requer-se cautela na aplicação de potássio nessa cultura, pois dose excessiva desse adubo é prejudicial à produtividade e à qualidade do fruto.

Palavras-chave: Musa spp., ocorrência de chilling, ótimo nas variáveis estudadas, produtividade observada

\section{Recebido para publicação em 12/07/2016. Aprovado em 19/10/2016.}

1 - Engenheiro Agrônomo, mestrando em agronomia, UnB/DF, douglasramoslorena@gmail.com

2 - Engenheiro Agrícola, doutor, professor associado da UnB/DF, cicero@unb.br

3 - Engenheiro Agrônomo, doutor, professor titular da UnB/DF, peixoto@unb.br

4 - Engenheiro Agrônomo, mestre em agronomia, UnB/DF, gustavo@unb.br

5 - Engenheiro Agrônomo, doutor, professor adjunto da UnB/DF, gervasiorios@unb.br 


\section{INTRODUCTION}

The banana (Musa spp.) is the most consumed fruit in the world, and in Brazil each inhabitant consumes up to $31 \mathrm{~kg}$ each year. Currently, India is the main world producer, producing 27.6 million tons. Brazil is the $4^{\text {th }}$ world producer, producing 6.9 million tons. Despite the huge volume of production, the Brazilian productivity is low, leaving the country in the $57^{\text {th }}$ position in the world ranking for productivity (FAO 2013).

In Brazil, the apple banana is the most valued kind of banana in the market; however, it is the most susceptible to the Panama disease (LEONEL \& DAMATTO JÚNIOR 2007). Hence, Embrapa Mandioca e Fruticultura experimental station launched a BRS Tropical Hybrid, originated from the diploid hybrid M53 and from the Yangambi Variety no. 2. The BRS Tropical Hybrid and the apple banana have similar taste, and, also, it is resistant to the yellow sigatoka and tolerant to the Panama disease. (SILVA et al. 2004).

Growth, development and productivity of the banana plant were influenced by soil, climate, genotype and management level. For the genotype to express its potential in productivity, technology is necessary, as well as a place with good weather condition for the plant development. (ROBINSON \& GALÁN SAÚCO 2010).

Many authors (COELHO et al. 2006;AZEVEDO et al. 2010; ALBUQUERQUE JÚNIOR et al. 2013; COSTA et al. 2012) described the importance of irrigation for the banana crop yield when compared to other tropical plants, since banana plants are sensitive to drought (VOSSELEN et al. 2005).

In most part of Brazil the banana plant needs more water than rain provides, because this plant's transpiration is higher than the water provided in many regions throughout the year (ROBINSON \& GALÁN SAÚCO 2010).

Plant nutrition is a decisive factor for growth, development and production; because a fast growth demands nutrients, consequently a good productivity is also obtained (SOARES et al. 2008). The nutritional demand of the banana plant is, in descending order, potassium, nitrogen, sulfur, magnesium, calcium and phosphor (HOFFMAN et al. 2010).
Ganeshamurthy et al. (2011) explain that, although it does not participate directly in the plant structure, the potassium absorption by the banana plant is important in catabolic reactions essential to the plant, such as breathing, chlorophyll formation, photosynthesis and water regulation. Other authors that have described potassium importance plants (WEBER et al. 2006; COSTA et al. 2009; SANTOS et al. 2009). However, further research is necessary to evaluate the combination of both fertilization and irrigation during banana production.

Regarding the city of Brasília and its surrounding, this region is characterized by an enormous amount of rain at the end of spring, during summer and the first half of fall. On the other hand, during the months through which dry climate prevails, especially June, July and August, the temperature at night can drop, in some occasions, to less than $12^{\circ} \mathrm{C}$, favoring plant frosting, a phenomenon that hampers banana plant development. Nevertheless, even regarding this adversity, it is common to see commercial orchards of this fruit, mostly among small producers.

Considering what has been exposed before, this research aimed to analyze quantitative aspects of productivity, referent to the first cycle of the 'BRS Tropical' banana production, under different doses of potassium fertilization and volumes of irrigation, given the climate in Distrito Federal.

\section{MATERIAL AND METHODS}

The experiment was performed between December, 2012 and December, 2014, on the Fazenda Água Limpa - (UnB) (FAL - UnB), which has the following geographic coordinates $15^{\circ} 56^{\prime} \mathrm{S}$ and $47^{\circ} 56^{\prime} \mathrm{W}$ and an altitude of 1080 meters. The climate classification, according the Köppen methods, is CWa type and it presents two well-defined seasons: the dry one, from the end of April to September, and a rainy one, from October to mid-April. The soil on the experimental area is a yellowish-red latosol and the terrain is $4 \%$ sloped.

In the experiment, micro spread seedlings were used from the banana hybrid 'BRS Tropical'. The field in which the orchard was planted had been previously prepared by using disk harrow, and $3.0 \times 3.0 \mathrm{~m}$ pits were dug with a volume of $1 \mathrm{~m}^{3}$ each. 
Soil samples were collected on the $0-20 \mathrm{~cm}$ and 20-40 cm layers, and, then, went through physicalchemical analysis. The results of the chemical analysis of the soil, as per the methodology proposed by Embrapa (1997), were: for the $0-20 \mathrm{~cm}$ layer, $\mathrm{pH}\left(\mathrm{H}_{2} \mathrm{O}\right) 6.02 ; \mathrm{H}+\mathrm{Al}\left(\mathrm{me} / 100 \mathrm{~cm}^{3}\right) 5.12$; and the concentrations, in $\mathrm{mg} \mathrm{L}^{-1}$, of $\mathrm{Al}^{3+} 1.26$; $\mathrm{P} 2.36$; $\mathrm{K}^{+} 50.00 ; \mathrm{Ca}^{2+} 645.00 \mathrm{Mg}^{2+} 216$ and the organic matter $1.81 \%$. On the $20-40 \mathrm{~cm}$ layer, the results were $\mathrm{pH}\left(\mathrm{H}_{2} \mathrm{O}\right) 6.21 ; \mathrm{H}+\mathrm{Al}\left(\mathrm{me} / 100 \mathrm{~cm}^{3}\right) 2.45$; and the concentrations, in $\mathrm{mg} \mathrm{L}^{-1}$, of $\mathrm{Al}^{3+} 0.54$; $\mathrm{P} 2.31$; $\mathrm{K}^{+}$40.00; $\mathrm{Ca}^{2+} 489.00 ; \mathrm{Mg}^{2+} 155.00$ and organic matter $1.31 \%$. According to the physical analysis, the soil has presented the following granulometry,

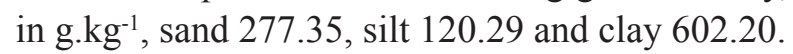

In order to correct the acidity of the soil, it was used the amount of 200 grams of dolomitic limestone per pit, then the plant were fertilized with 500 grams of simple superphosphate, 200 grams of magnesium thermophosphate and 50 grams of FTE per pit. Crop management practices were in agreement with Alves et al. (2004) recommendation.

After planting the seedlings, a drip irrigation system composed by two operational units was installed. Each operational unit was formed by 40 sidelines, two for each row of plant, distant approximately $50 \mathrm{~cm}$ from each other. The tubing used on the sidelines was made out of polyethylene with $16 \mathrm{~mm}$ of intern diameter and $60 \mathrm{~m}$ of length. On the side lines, drippers were installed with flux of 2, 4 and 8 liters per hour $\left(\mathrm{L} \mathrm{h}^{-1}\right)$. Those drippers were organized in order to be able to flow $4 \mathrm{~L} \mathrm{~h}^{-1}$ (formed by two drippers of $2 \mathrm{~L} \mathrm{~h}^{-1}$ ), $8 \mathrm{~L} \mathrm{~h}^{-1}$ (4 drippers of $2 \mathrm{~L} \mathrm{~h}^{-1}$ ), $16 \mathrm{~L} \mathrm{~h}^{-1}$ (4 drippers of $4 \mathrm{~L} \mathrm{~h}^{-1}$ ), $24 \mathrm{~L} \mathrm{~h}^{-1}$ (2 drippers of $4 \mathrm{~L} \mathrm{~h}^{-1}$ and 2 drippers of $\left.8 \mathrm{~L} \mathrm{~h}^{-1}\right)$ and $32 \mathrm{~L} \mathrm{~h}^{-1}\left(4\right.$ drippers of $\left.8 \mathrm{~L} \mathrm{~h}^{-1}\right)$. At the volume of $4 \mathrm{~L} \mathrm{~h}^{-1}$, the drippers were put in each 3.0 meters on the side line, while at the volumes of $8,16,24$ and $32 \mathrm{~L} \mathrm{~h}^{-1}$, the space was 1,0 meter between the drippers and 2,0 meters between the group of two drippers.

The experiment was carried out in four blocks entirely randomized in a factorial $5 \times 5$ arrangement, in split-plot design. The five water volumes (W) applied in accordance to the parcels were 1090 $2177-4300-6540-8720$ liters per pit, equivalent with the depths $121 \mathrm{~mm}, 242 \mathrm{~mm}, 478 \mathrm{~mm}, 727 \mathrm{~mm}$ and $969 \mathrm{~mm}$ regarding the range of $9 \mathrm{~m}^{2}$ for each pit. Those volumes were obtained by multiplying the volume used in each pit by the time of irrigation and the quantity of irrigation used throughout the experiment. The operational units which received five doses of potassium (K) $0-167-334-500-$ $667 \mathrm{~kg} \cdot \mathrm{ha}^{-1}$ of $\mathrm{K}_{2} \mathrm{O}$ were considered experimental units. Each experimental unit was formed by four useful pits, consisting a total of 400 pits.

The irrigation was performed based on the culture evapotranspiration (ETc) and the established coefficient was considered according to the percentage formed by the relation between the wet area and the area destined to each pit, according to Lorena (2015). The ETc was calculated with the Penman - Monteith - FAO equation, using climate data from a station near to the experimental area. Irrigation began after a long rainy period in 2013 and continued until the beginning of the next rainy period. The total number of irrigation, the irrigation length, as well as the water volumes applied throughout the experiment may be seen in Table 1. The increase in irrigation time shown on the given chart aimed to manage the water volumes applied according to the variation in the culture coefficient $(\mathrm{Kc})$, which increased with the plant development. The irrigation lengths were established aiming to get irrigation volumes that would be deficient, adequate and excessive regarding the hydric demand of the culture. It is important to highlight that the chosen handling allows the quantification of the optimal water volumes applied to each dependent variable that was studied.

Besides the potassium fertilization, the plants were fertilized with $167 \mathrm{~kg} \cdot \mathrm{ha}^{-1}$ of $\mathrm{P}_{2} \mathrm{O}_{5}$ and $172 \mathrm{~kg} \cdot \mathrm{ha}^{-1}$ of $\mathrm{N}$. The fertilizing doses were obtained from the average of the fertilization recommendations for banana orchards cultured in the states of Goiás, Minas Gerais, Santa Catarina and São Paulo.

The fertilizations were fractioned in 10 applications distributed manually at a distance of $50 \mathrm{~cm}$ from the pseudostem. After the applications, the fertilizers were incorporated to the soil with the help of a hoe. The sources of N, P and K were urea, simple superphosphate and potassium chlorate, respectively.

To evaluate the agronomic performance of the 
Table 1. Irrigation volumes used based on the volume discharge in each pit for the total amount of irrigation, irrigation length and reference evapotranspiration $\left(\mathrm{ET}_{0}\right)$ during the irrigation periods in Brasília in 2013 and 2014.

\begin{tabular}{|c|c|c|c|c|c|c|c|c|}
\hline \multirow{3}{*}{ Year/Month } & \multirow{3}{*}{$\begin{array}{l}\text { Total of } \\
\text { irrigation } \\
\text { per month }\end{array}$} & \multirow{3}{*}{$\begin{array}{l}\text { Reference evapotranspiration, in } \\
\mathrm{mm} \text {, acumulated on the periods } \\
\text { that normalized irrigation }\end{array}$} & \multirow{3}{*}{$\begin{array}{l}\text { Time of } \\
\text { irrigation } \\
\text { in hours }\end{array}$} & \multicolumn{5}{|c|}{ Flow used per pit (Liters/pit) } \\
\hline & & & & 4 & 8 & 16 & 24 & 32 \\
\hline & & & & \multicolumn{5}{|c|}{ Volume of water applied per pit - in liters } \\
\hline Jul-13 & 16 & 79,89 & 1,00 & 64 & 128 & 256 & 384 & 512 \\
\hline Aug-13 & 15 & 103,19 & 1,25 & 75 & 150 & 300 & 450 & 600 \\
\hline Sep-13 & 15 & 107,87 & 1,50 & 90 & 180 & 360 & 540 & 720 \\
\hline Oct-13 & 6 & 25,87 & 1,75 & 42 & 84 & 168 & 252 & 336 \\
\hline $\operatorname{Jan}-14$ & 6 & 84,59 & 1,75 & 42 & 84 & 168 & 252 & 336 \\
\hline Feb-14 & 2 & 45,20 & 1,75 & 14 & 28 & 56 & 84 & 112 \\
\hline May-14 & 16 & 79,09 & 1,75 & 112 & 224 & 448 & 672 & $\$ 96$ \\
\hline Junn-14 & 15 & 66,26 & 1,75 & 105 & 210 & 420 & 630 & 840 \\
\hline Jul-14 & 16 & 71,23 & 1,75 & 112 & 224 & 448 & 672 & $\$ 96$ \\
\hline Aug-14 & 15 & 98,84 & 1,75 & 105 & 210 & 420 & 630 & 840 \\
\hline Sep-14 & 16 & 113,64 & 1,75 & 112 & 224 & 448 & 672 & $\$ 96$ \\
\hline Oct-14 & 15 & 117,67 & 1,75 & 105 & 210 & 420 & 630 & 840 \\
\hline Nov-14 & 16 & 93,67 & 1,75 & 112 & 224 & 448 & 672 & 896 \\
\hline Total & - & 1087,01 & - & 1090 & 2177 & 4300 & 6540 & 8720 \\
\hline
\end{tabular}

'BRS Tropical' banana plant, under the different proposed treatments, the bunches were harvested as soon as the fingers reached the full physiologic development, based on the reduction and/or disappearance of the corners and angularities from the finger surface, according to Alves et al. (2004).

Bunches were harvested between July $1^{\text {st }}$, 2014 and December 30 3014 with a weekly break between the harvests, consisting in total 27 harvests. These bunches were divided into hands so that it could be possible to count the number of hands in each bunch and the number of fingers in each hand. Afterwards, the hands of each bunch were weighted. To get the average length and diameter of the fruit, we took randomly 5 fingers from the upper, middle and lower hands, totalizing 15 fingers analyzed per bunch.

The results evaluated were productivity (PD) in kg.ha- ${ }^{-1}$, obtained from the hand mass; number of hands (NC); number of hands per bunch (NPC); number of fingers per bunch (NBC); number of fingers per hand (NBP); average mass of the fruit (MMF), in grams; average length of the fruit (CMF), in $\mathrm{mm}$; average diameter of the fruit (DMF), in $\mathrm{mm}$; relation length diameter (CD) and the firmness of the pulp (FP), in $\mathrm{kPa}$.

The variables data were assessed through analysis of variance (ANOVA) and regression analysis from the complete polynomial equation, as proposed by Oliveira Júnior et al., (2010) and Boschini et al. (2010).

$\mathrm{Y}=\mathrm{b}_{0}+\mathrm{b}_{1} \mathrm{~W}+\mathrm{b}_{2} \mathrm{~K}+\mathrm{b}_{3} \mathrm{~W}^{2}+\mathrm{b}_{4} \mathrm{~K}^{2}+\mathrm{b}_{5} \mathrm{WK}$

In which,

$\mathrm{Y}=$ variable answer in relation to potassium fertilization dose $(\mathrm{K})$ and volume of irrigation (W) applied;

$\mathrm{W}=$ volume of water applied per additional irrigation (liter per pit);

$\mathrm{K}=$ potassium dose $\left(\mathrm{K}_{2} \mathrm{O}\right)$ applied $\left(\mathrm{kg} \cdot \mathrm{ha}^{-1}\right)$; and $\mathrm{b}_{0}, \mathrm{~b}_{1}, \mathrm{~b}_{2}, \mathrm{~b}_{3}, \mathrm{~b}_{4}, \mathrm{~b}_{5}=$ coefficients related to the regression terms. 
Quadratic regression model allows the determination, in case there is significance in the coefficients, of the optimum of the variables studied in relation to the proposed factors of production. The statistical analyses were made with the statistics program SISVAR (FERREIRA 1998). Field conditions did not make it possible to control the involved parameters in the culture development and, therefore, despite using micro propagated seedlings in this experiment, a certain heterogeneity on the culture development was observed. Hence, in this experiment we decided to increase the level of significance in the statistical model to $30 \%$.

\section{RESULTS AND DISCUSSION}

To facilitate the visualization of the variable answers obtained in relation to production parameters, doses of irrigation per pit and doses of potassium per hectare, Table 2 was organized in which the biggest productivity can be seen to be $11.752 \mathrm{~kg} \cdot \mathrm{ha}^{-1}$, corresponding to the dose of 500 $\mathrm{kg} \cdot \mathrm{ha}^{-1}$ of $\mathrm{K}_{2} \mathrm{O}$ and 6.540 liters of water per pit.

The productivities were low when compared to the results found by Ramos et. al. (2009), who observed the productivity of the 'BRS Tropical' banana plant of 26,7 t.ha $^{-1}$ conducted in the state of São Paulo. This result can be justified by the occurrence of 192 minimum temperatures under $12^{\circ} \mathrm{C}$ during the period through which their experiment took place. In 2013, the low temperatures were mainly in July and August, although, sporadically, there were some low temperatures at night under $12^{\circ} \mathrm{C}$ on September. In 2014, the temperature decreased in May and

Table 2. Values observed from the variable answers studied, PD in $\mathrm{Kg}^{-h^{-1}}{ }^{-1} \mathrm{NC}, \mathrm{NPC}, \mathrm{NBC}$, MMF in grams, CMF in $\mathrm{mm}, \mathrm{DMF}$ in $\mathrm{mm}, \mathrm{CD}$ and FMP in $\mathrm{KPa}$, in relation to the doses of potassium $(\mathrm{K})$ and the volume of water applied per pit (W).

\begin{tabular}{|c|c|c|c|c|c|c|c|c|c|c|c|}
\hline w & $\mathrm{K}$ & $\mathrm{PD}\left(\mathrm{Kg}_{\mathrm{g}} \mathrm{ha}^{-1}\right)$ & $\mathrm{NC}$ & NPC & $\mathrm{NBC}$ & NBP & MMF (grams) & $\mathrm{CMF}(\mathrm{mm})$ & $\mathrm{DMF}(\mathrm{mm})$ & $\mathrm{CD}$ & $\mathrm{FP}(\mathrm{Kpa})$ \\
\hline \multirow{5}{*}{$\mathrm{w}_{1}$} & $\mathrm{~K}_{1}$ & 1195,4 & 347,5 & 5,62 & 75,37 & 13,42 & 45,58 & $\$ 6,44$ & 27,36 & 3,21 & 6,75 \\
\hline & $\mathrm{K}_{2}$ & 4343,7 & 625,5 & 6,02 & 75,65 & 12,49 & 85,10 & 112,12 & 34,30 & 3,30 & 8,75 \\
\hline & $\mathrm{K}_{3}$ & 8291,3 & 973,0 & 6,04 & 85,77 & 14,19 & 96,76 & 113,78 & 36,97 & $3,0 \mathrm{~s}$ & 8,68 \\
\hline & $\mathrm{K}_{4}$ & 5963,1 & 764,5 & 5,67 & 74,54 & 13,03 & 94,38 & 108,95 & 34,12 & 3,21 & 7,92 \\
\hline & $\mathrm{K}_{5}$ & 3975,4 & 556,0 & 6,12 & 85,21 & 13,85 & 87,85 & 104,03 & 35,82 & 2,92 & 5,03 \\
\hline \multirow{5}{*}{$\mathrm{w}_{2}$} & $\mathrm{~K}_{1}$ & 5143,0 & 625,5 & 6,21 & 85,12 & 13,75 & 92,44 & 116,54 & 35,67 & 3,27 & 9,92 \\
\hline & $\mathrm{K}_{2}$ & 7624,1 & 903,5 & 6,48 & 94,75 & 14,77 & 90,60 & 107,31 & 34,48 & 3,13 & 7,30 \\
\hline & $\mathrm{K}_{3}$ & 6956,9 & 903,5 & 5,67 & 80,48 & 14,15 & 95,30 & 113,56 & 35,88 & 3,16 & 6,89 \\
\hline & $\mathrm{K}_{4}$ & 9924,6 & 1042,5 & 6,10 & 88,98 & 14,64 & 104,07 & 119,77 & 36,95 & 3,24 & 9,65 \\
\hline & $\mathrm{K}_{5}$ & 5956,1 & 695,0 & 6,56 & 88,44 & 13,51 & 99,58 & 112,19 & 35,98 & 3,12 & 5,99 \\
\hline \multirow{5}{*}{$w_{3}$} & $\mathrm{~K}_{1}$ & 2411,6 & 556,0 & 4,96 & 67,17 & 13,43 & 63,22 & 93,00 & 29,38 & 3,17 & 7,58 \\
\hline & $\mathrm{K}_{2}$ & 5469,6 & 764,5 & 5,87 & 75,12 & 12,77 & 94,41 & 111,22 & 35,50 & 3,14 & 7,30 \\
\hline & $\mathrm{K}_{3}$ & 4343,7 & 556,0 & 5,83 & 81,75 & 13,96 & 99,65 & 116,52 & 36,61 & 3,19 & 9,71 \\
\hline & $\mathrm{K}_{4}$ & 4218,6 & 486,5 & 5,71 & 78,21 & 13,71 & 107,35 & 121,39 & 37,60 & 3,24 & 9,78 \\
\hline & $\mathbf{K}_{5}$ & 7422,6 & 695,5 & 6,25 & 94,33 & 15,10 & 116,33 & 114,00 & 36,53 & 3,13 & 7,92 \\
\hline \multirow{5}{*}{$\mathrm{w}_{4}$} & $\mathrm{~K}_{1}$ & 5838,0 & 625,7 & 6,56 & 88,44 & 13,52 & 100,51 & 120,09 & 36,90 & 3,26 & 5,93 \\
\hline & $\mathrm{K}_{2}$ & 5386,2 & 764,5 & 5,87 & 75,25 & 12,87 & 89,19 & 111,43 & 33,62 & 3,28 & 9,51 \\
\hline & $\mathrm{K}_{3}$ & 8117,6 & 903,5 & 5,84 & 80,33 & 13,90 & 105,14 & 113,40 & 35,21 & 3,24 & 6,34 \\
\hline & $\mathrm{K}_{4}$ & 11752,4 & 1042,5 & 6,46 & 94,29 & 14,60 & 121,10 & 120,67 & 40,17 & 2,65 & 6,48 \\
\hline & $\mathbf{K}_{5}$ & 7770,1 & 695,0 & 7,25 & 144,21 & 15,71 & 105,29 & 116,02 & 37,56 & $3,0 \mathrm{~s}$ & 8,82 \\
\hline \multirow{5}{*}{$\mathrm{w}_{5}$} & $\mathrm{~K}_{1}$ & 2439,4 & 417,0 & 4,87 & 65,00 & 13,37 & 95,51 & 107,02 & 29,27 & 3,92 & 9,71 \\
\hline & $\mathrm{K}_{2}$ & 4559,2 & 625,0 & 5,96 & 78,87 & 13,20 & 86,00 & 108,98 & 34,50 & 3,16 & 9,09 \\
\hline & $\mathrm{K}_{3}$ & 8937,7 & 1042,5 & 5,71 & 77,02 & 13,55 & 110,81 & $117,8 s$ & 37,60 & 3,15 & 4,96 \\
\hline & $\mathrm{K}_{4}$ & 8791,7 & 1042,5 & 5,92 & 81,10 & 13,63 & 100,31 & 113,98 & 34,09 & 2,81 & 7,72 \\
\hline & $\mathrm{K}_{5}$ & 6646,5 & 834,0 & 6,10 & 79,96 & 13,10 & 99,40 & 113,36 & 35,98 & 3,16 & 6,27 \\
\hline
\end{tabular}

Productivity (PD); Number of bunches (NC); number of hands per bunch (NPC); number of fingers per bunch (NBC); number of fingers per hand (NBP); average mass of the fruit (MMF); average length of the fruit (CMF); average diameter of the fruit (DMF); relation length/diameter (CD); average firmness of the pulp (FPMP). The irrigation volumes were $\mathrm{W}_{1} ; \mathrm{W}_{2} ; \mathrm{W}_{3} ; \mathrm{W}_{4} ; \mathrm{W}_{5}$ respectively for the volumes of $1090-2177-4300-6540-8720$ liters per pit corresponding to the depths $121 \mathrm{~mm}, 242 \mathrm{~mm}, 478 \mathrm{~mm}, 727 \mathrm{~mm}$ and $969 \mathrm{~mm}$. Potassium doses $(\mathrm{K}), \mathrm{K}_{1} ; \mathrm{K}_{2} ; \mathrm{K}_{3} \mathrm{~K}_{4} ; \mathrm{K}_{5}$ correspond to the doses $0-167-334-500-667 \mathrm{Kg} \cdot \mathrm{ha}^{-1}$. 
followed the occurrences of the previous year. The occurrence of temperatures under $12^{\circ} \mathrm{C}$ at night may be responsible for the physiologic phenomenon known as plant frost, which may cause a decrease in the orchard productivity (BORGES \& SOUZA 2004).

The variance analysis for number of fingers per bunch (NBC) and average length of the fruit (CMF) showed significant interaction between the variables volume of irrigation (W) and potassium fertilization (K). According to the level of water, the potassium presented positive influence in the total number of bunches (NTC), the average mass of the fruit (MMF) and the average diameter of the fruit (DMF), considering that all equations showed quadratic adjustment, which emphasizes the importance of this nutrient for the banana culture. These results are in accordance with Santos et al. (2009) and Martins et al. (2011). Productivity (PD), number of hands per bunch (NPC) and number of fingers per hand $(\mathrm{NBC})$ responded significantly to volumes of irrigation as well as to potassium fertilization (Table 3).

Although the variance analysis points that the influencing variable $\mathrm{W}$ affected significantly the $\mathrm{PD}$, the coefficients related to the terms $\mathrm{W}$ and $\mathrm{W}^{2}$ presented a level of significance higher than $30 \%$, therefore they were taken away from the proposed model. Moreover, the non-significance of the variable $\mathrm{W}$ in the proposed statistical model is due to, probably, the total amount of precipitation in the period from January, 2013 to November, 2014, which was $3.131,8 \mathrm{~mm}$. This precipitation would be sufficient to supply the hydric demand of the crop if it were not for the seasonality on its distribution.

Due to the non-significance of the factor water applied W, productivity was described only in relation to potassium fertilizations, (Equation 3, Table 4 and Figure 1). When maximizing the variable answer $\mathrm{PD}$ in relation to the influencing variable $\mathrm{K}$, an optimal dose of $\mathrm{K}_{2} \mathrm{O}$ equivalent to $448,66 \mathrm{Kg} \cdot \mathrm{ha}^{-1}$ was found, along with the adjusted productivity of $7.688,3 \mathrm{Kg} \cdot \mathrm{ha}^{-1}$. The optimized dose of potassium in the current study was near to the one found by Santos et. al (2009), in works done in the Brazilian Northeast. Those authors discovered that a dose of $470 \mathrm{Kg} \cdot \mathrm{ha}^{-1}$ of $\mathrm{K}_{2} \mathrm{O}$ provided a bigger production of bananas. Nevertheless, Costa et al. (2012), in experiments conducted in the Bahia coast verified that doses of $\mathrm{K}_{2} \mathrm{O}$, ranging from 0 to 1.200 Kg.ha ${ }^{-1}$, did not influence banana production during the first production cycle. According to these authors, the concentration of $93,84 \mathrm{mg} . \mathrm{L}^{-1}$ of $\mathrm{K}$ in the soil satisfied the demand of the plant during the first year of production. However, the concentration of $\mathrm{K}_{2} \mathrm{O}$ in the soil where the present experiment was set up was low at $50 \mathrm{mg} \cdot \mathrm{L}^{-1}$, which can justify how the banana plant responded to potassium during the first production cycle.

Table 3: Analysis of variance (ANOVA) for productivity, number of hands, number of hands per bunch, number of fingers per bunch, number of fingers per hand, average mass of the fruit, average length of the fruit, average diameter of the fruit, relation length/diameter and average firmness of the pulp in relation to the volumes of water applied per pit (W) and doses of potassium fertilization (K). Brasília, DF, 2014.

\begin{tabular}{|cccccccccccc|}
\hline \multirow{2}{*}{ FV } & \multirow{2}{*}{ G.L } & \multicolumn{10}{c|}{ MEDIUM SQUARE } \\
\cline { 2 - 11 } & & PD & NC & NPC & NBC & NBP & MMF & CMF & DMF & CD & FMP \\
\hline Block & 3 & $18160417,6^{\mathrm{n}}$ & $66979,5^{\mathrm{n}}$ & $0,80^{\mathrm{n}}$ & $398,28^{*}$ & $2,12^{\mathrm{n}}$ & $798,9^{\mathrm{n}}$ & $84,28^{\mathrm{n}}$ & $9,95^{\mathrm{n}}$ & $0,19^{\mathrm{n}}$ & $0,06^{\mathrm{n}}$ \\
W & 4 & $37181643,7^{*}$ & $1999779,1^{\mathrm{n}}$ & $1,86^{* *}$ & $743,18^{* *}$ & $2,90^{*}$ & $1351,4^{\mathrm{n}}$ & $353,13^{* *}$ & $28,03^{\mathrm{n}}$ & $0,05^{\mathrm{n}}$ & $0,12^{\mathrm{n}}$ \\
K & 4 & $66694123,4^{* *}$ & $449020,2^{* *}$ & $1,83^{* *}$ & $735,35^{* *}$ & $3,30^{*}$ & $2362,6^{* *}$ & $455,31^{* *}$ & $87,51^{*}$ & $0,33^{\mathrm{n}}$ & $0,18^{\mathrm{n}}$ \\
WxK & 16 & $11078665,1^{\mathrm{n}}$ & $86268,3^{\mathrm{n}}$ & $0,51^{\mathrm{n}}$ & $244,89^{*}$ & $1,86^{\mathrm{n}}$ & $494,4^{\mathrm{n}}$ & $183,13^{* *}$ & $19,62^{\mathrm{n}}$ & $0,18^{\mathrm{n}}$ & $0,25^{\mathrm{n}}$ \\
\hline CV 1 (\%) & - & 48,2 & 42,73 & 8,95 & 10,83 & 6,57 & 24,16 & 6,37 & 11,9 & 12,51 & 59,35 \\
CV 2 (\%) & - & 53,78 & 46,79 & 9,44 & 12,57 & 8,04 & 21,03 & 7,09 & 9,41 & 11,82 & 40 \\
\hline
\end{tabular}

Productivity (PD); number of bunches (NC); number of hands per bunches (NPC); number of fingers per bunch (NBC); number of fingers per hands (NBP); average mass of the fruit (MMF); average length of the fruit (CMF); average diameter of the fruit (DMF); relation length/diameter (CD); average firmness of the pulp (FMP); variance source (FV); degrees of freedom (GL); coefficient of variation (CV $1 ; \mathrm{CV} 2) ;{ }^{* *},{ }^{*}$ and $\mathrm{n}$ correspond, respectively, to the significances at $1 \%$ and $5 \%$ and non-significant, to $5 \%$, for the Test F. 
Table 4. Regression equations of productivity (PD) and of parameters number of bunches (NC), average length of the fruit (CMF), average mass of the fruit (MMF) and average diameter of the fruit (DMF), of the 'BRS Tropical' banana plant in relation to the volume of water applied per pit (W) and potassium fertilization $(\mathrm{K})$.

\begin{tabular}{|c|c|c|}
\hline $\mathrm{N}^{\circ}$ of the equation & Equation Regression & $\mathrm{R}^{2}(\%)$ \\
\hline 2 & $\mathrm{PD}=3.179,3+20,10^{* 4} \mathrm{~K}-0,0224^{*} \mathrm{~K}^{2}$ & 97,79 \\
\hline 3 & $\mathrm{NC}=565,75-0,027^{\mathrm{n}} \mathrm{W}+1,6 \mathrm{~S}^{* *} \mathrm{~K}+0,000002^{\mathrm{n}} \mathrm{W}^{2}-0,0024^{* *} \mathrm{~K}^{2}+0,00005^{\dagger}(\mathrm{WxK})$ & 50,86 \\
\hline 4 & $\mathrm{CMF}=95,0 \mathrm{~S}+0,0041^{\circ} \mathrm{W}+0,05^{*} \mathrm{~K}-0,0000003^{\circ 8} \mathrm{~W}^{2}-0,00006^{*} \mathrm{~K}^{2}$ & 42,26 \\
\hline 5 & $\mathrm{MMF}=52,94+0,009 \mathrm{~s}^{*} \mathrm{~W}+0,11^{+*} \mathrm{~K}-0,0000007^{\circ} \mathrm{W}^{2}-0,00009^{\circ} \mathrm{K}^{2}-0,000004^{\dagger}(\mathrm{W} \times \mathrm{K})$ & 62,53 \\
\hline 6 & $\mathrm{DMF}=29,24+0,0014^{\circ} \mathrm{W}+0,02^{*} \mathrm{~K}-0,0000001^{\circ} \mathrm{W}^{2}-0,00002^{*} \mathrm{~K}^{2}$ & 53,46 \\
\hline
\end{tabular}

Productivity (PD) in $\mathrm{Kg} \mathrm{ha}^{-1}$; number of bunches (NC); average mass of the fruit (MMF) in grams; average length of the fruit $(\mathrm{CMF})$ in $\mathrm{mm}$; average diameter of the fruit (DMF) in mm; volume of irrigation (W) in liters per pit ${ }^{-1}$; potassium fertilization (K) in Kg.ha ${ }^{-1} ;{ }^{* *},{ }^{*}, \circ,{ }^{\circ},{ }^{\dagger} \mathrm{n}$ correspond to, respectively, to the significances $1 \%, 5 \%, 10 \%, 20 \%, 30 \%$ and non-significant.

As for the number of bunches (NC), it was possible to stablish the Equation 3 in relation to the volumes of irrigation and the doses of $\mathrm{K}$. It is essential to point that, despite the variance analyses not showing the interaction among the factors, the regression coefficient related to the term $(\mathrm{KxW})$ presented a significance degree lower than $30 \%$, therefore remaining in the model. Besides, although the coefficients related to the terms $\mathrm{W}$ and $\mathrm{W}^{2}$ did not show any significance, they were kept in the experiment, because their withdrawal would imply a big reduction in the coefficient of determination for the proposed model.

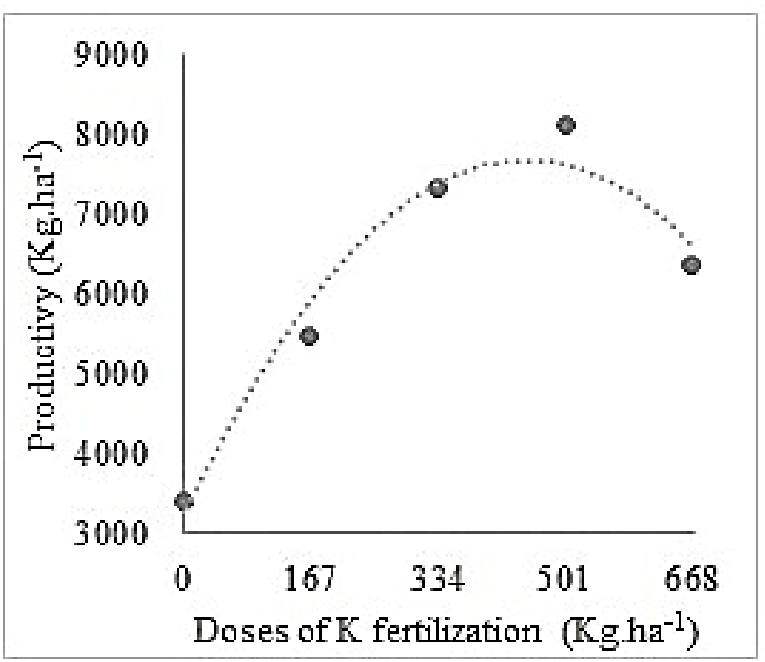

Figure 1. Productivity of the 'BRS Tropical' banana plant observed (points) and adjusted (lines), in $\mathrm{Kg}_{\mathrm{h}} \mathrm{ha}^{-1}$, in relation to the five levels of potassium fertilization used. Brasilia, 2014.
Considering the Equation 3 seen on Table 4, Figure 2 was made to illustrate the variable $\mathrm{NC}$ behavior according to the variables $\mathrm{W}$ and $\mathrm{K}$ influences. Based on equation 3, the optimal doses of $\mathrm{K}_{2} \mathrm{O}$ for each volume of irrigation were established. The volume of irrigation was 8.720 liters per pit and the dose of $\mathrm{K}_{2} \mathrm{O}$ of $440,83 \mathrm{Kg} \cdot \mathrm{ha}^{-1}$ were noticed to take a production adjusted to 949 bunches per hectare. It has not been observed significance of the parameters of production on the variable answers number of hands per bunch and number of fingers per bunch.

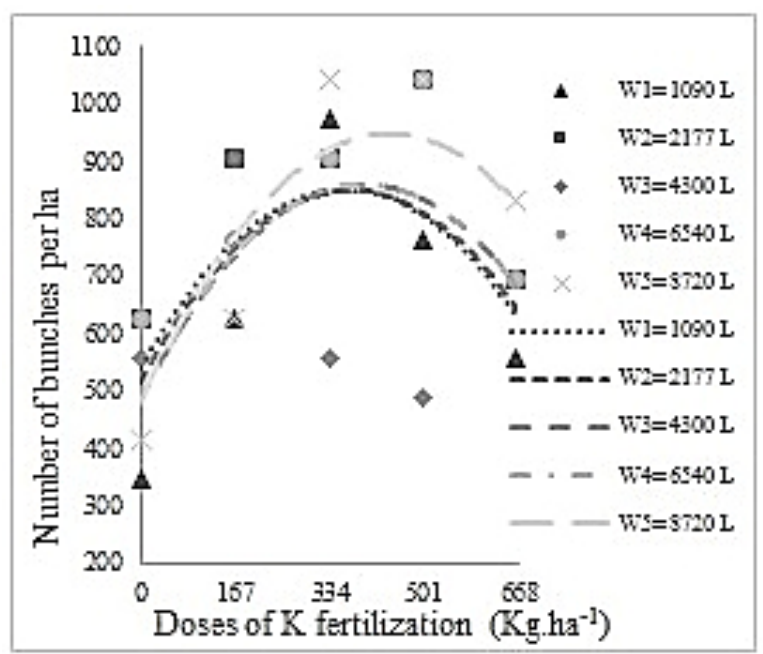

Figure 2. Number of bunches observed (dots) and adjusted (lines), per hectare, of the 'BRS Tropical' banana plant, in relation to the potassium fertilization used $(0-$ $167-334-500-667 \mathrm{Kg} \cdot \mathrm{ha}^{-1}$ ) into each volume of water applied per pit (W1 - W2 - W3 - W4 - W5). Brasília, 2014. 
Regarding the average length of the fruit (CMF), it was possible to establish the equation 4 (Table 4), highlighting a quadratic effect for the potassium fertilization levels as well as for the volumes of irrigation. Due to this fact, it was possible to maximize the average length of the fruit in relation to the influencing variables and the optimal doses were $450 \mathrm{Kg}$.ha ${ }^{-1}$ of $\mathrm{K}_{2} \mathrm{O}$ and 6.833 liters per pit, providing an adjusted CMF of 119,9 $\mathrm{mm}$. The graphic visualization of this can be seen on Figure 3. The level of $\mathrm{K}_{2} \mathrm{O}$ optimized during this work in relation to the variable CMF differed from that found by Martins et al. (2011), in which the authors accused a positive interaction between the irrigation blades and doses of $\mathrm{K}_{2} \mathrm{O}$.

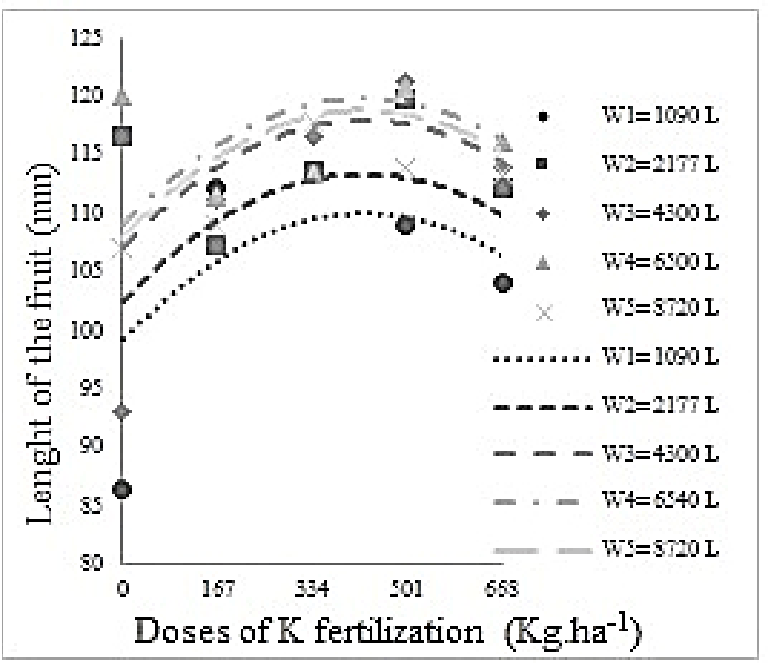

Figure 3. Average length of the fruit observed (dots) and adjusted (lines) in $\mathrm{mm}$, of the 'BRS Tropical' banana plant, in relation to the potassium fertilization used $(0-$ $167-334-500-667 \mathrm{Kg}$ ha $\left.{ }^{-1}\right)$ into each volume of water applied per pit (W1 W2 - W3 - W4 - W5). Brasília, 2014.

Regarding the average mass of the fruit, equation 5 (Table 4) was established in relation to the factors $\mathrm{W}$ and $\mathrm{K}$. It is important to bring up that, although the variance analysis did not indicate significant interaction among the factors, the withdrawal of the term $(\mathrm{KxW})$ would reduce expressively the coefficient of determination for the model, hence it was kept in the equation. When optimizing the doses of $\mathrm{K}_{2} \mathrm{O}$ for each volume of irrigation, the volume of irrigation of 6.540 liters per pit and $540 \mathrm{Kg} \cdot \mathrm{ha}^{-1}$ of $\mathrm{K}_{2} \mathrm{O}$ resulted in the biggest estimated mass of the fruit, 108,7 grams, which can be seen on Figure 4. The influence of potassium on the average mass of the fruits, as well as on the productivity, is related to the translocation of photoassimilates and hydric regulation, as stated by Ganeshamurthy et. al. (2011).

Equation 6 describes the average diameter of the fruit in relation to the volumes of irrigation and doses of $\mathrm{K}_{2} \mathrm{O}$ used. Although the variance analysis does not show significance in variable $\mathrm{W}$ over the dependent variable average diameter of the fruit (DMF), the coefficients of the model related to the terms $\mathrm{W}$ and $\mathrm{W}^{2}$ were significant in the regression model, hence they were kept in equation 6 , so that Figure 5 could be made. There is a quadratic effect at the figure 5 for the volumes of irrigation as well as for the potassium doses. Besides, a maximized value of DMF at $39,2 \mathrm{~mm}$ was found with 500 $\mathrm{Kg} \mathrm{ha}^{-1}$ of $\mathrm{K}_{2} \mathrm{O}$ and 7.000 liters per additional irrigation plant. This result differed from that found by Crisostomo et al. (2008) and Teixeira et al. (2008), who did not observe the influence of potassium fertilization on the fruit diameter during the first production cycle.

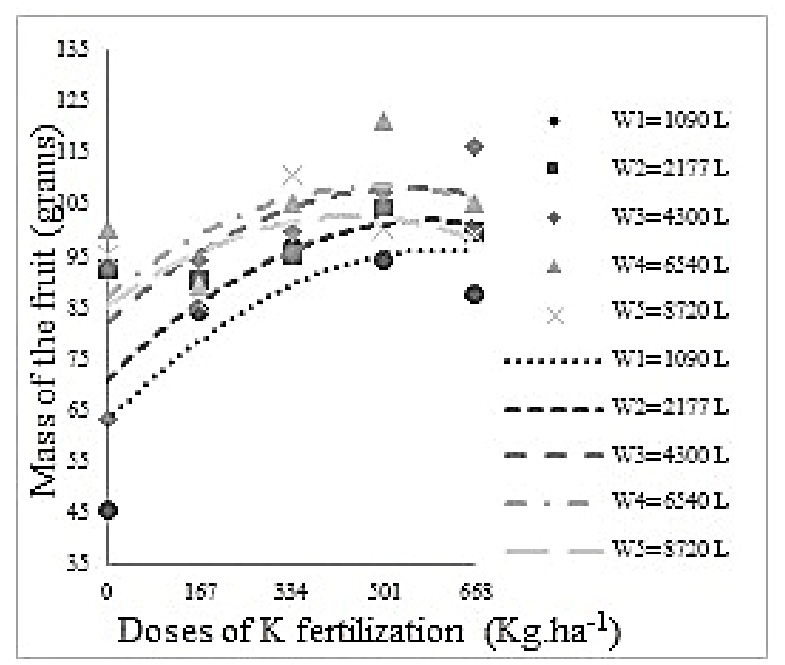

Figure 4. Average mass of the fruit observed (dots) and adjusted (lines) in grams, of the 'BRS Tropical' banana plant, in relation to the potassium fertilization used $(0-$ $\left.167-334-500-667 \mathrm{Kg} \mathrm{ha}^{-1}\right)$ into each volume of water applied per pit (W1 W2 - W3 - W4 - W5). Brasília, 2014. 


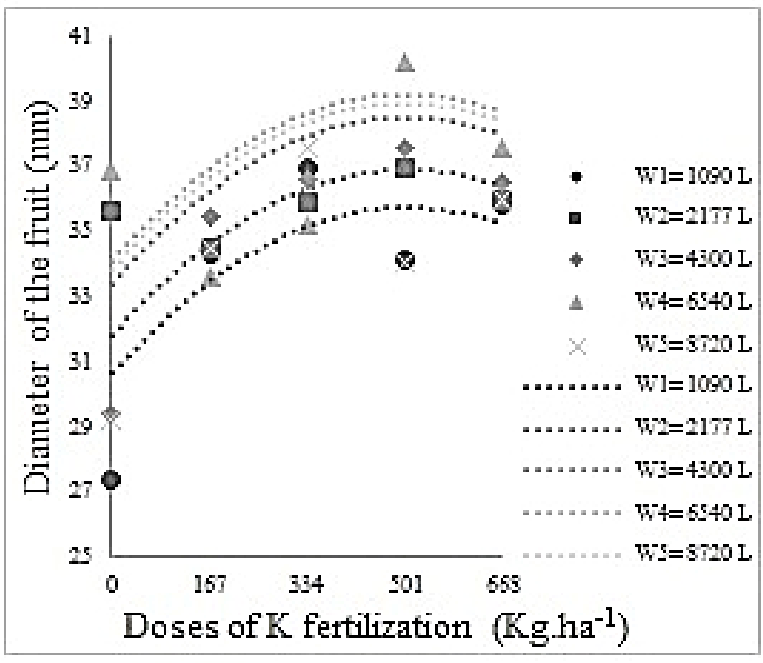

Figure 5. Average diameter of the fruit observed (dots) and adjusted (lines) in $\mathrm{mm}$, of the 'BRS Tropical' banana plant, in relation to five doses of potassium fertilization $\left(0-167-334-500-667 \mathrm{Kg}^{-h^{-1}}\right)$ and five volumes of water applied per pit (W1 - W2 - W3 - W4 - W5). Brasília, 2014.

\section{CONCLUSIONS}

- Potassium provides increments on the 'BRS Tropical' banana plant productivity, total number of bunches, number of hands per bunch, number of fingers per bunch and number of fingers per hand;

- The volume of irrigation affects positively the number of hands, the number of fingers per bunch, the number of fingers per hand and the average length of the fruit;

- High doses of potassium harm the fruit quality.

\section{BIBLIOGRAPHICAL REFERENCES}

ALBUQUERQUE JUNIOR, B.S.; GOMES, E.R.; SOUSA, A.P.; Necessidade Hídrica e lâminas de irrigação da bananeira $\mathrm{CV}$. FHIA-18 na região semiárida do Piauí. Irriga, Botucatu, v.18, n.4, p.756-767. 2013.

ALVES, E.J.; LIMA, M.B.; CARVALHO, J.E.; BORGES, A.L. Tratos culturais e colheita. In: BORGES, A.L.; SOUZA, L.S. (ed.). O cultivo da bananeira. Embrapa Mandioca e Fruticultura. Cruz das Almas, BA. 2004. p.107-130.

AZEVEDO, J.H.O.; BEZERRA, F.M.L. Resposta de dois cultivares de bananeira a diferentes lâminas de irrigação. Revista Ciência Agronômica, Fortaleza, v.39, n.2, p.28-33. 2008.

BORGES, A.L.; SOUZA, L.S. Exigências edafoclimáticas. In: BORGES, A.L.; SOUZA, L.S. (ed.). $O$ cultivo da bananeira. Embrapa Mandioca e Fruticultura. Cruz das Almas, BA. 2004. p.15-22.

BOSCHINI, A.P.M.; SILVA, C.L.; OLIVEIRA, C.A. S.; OLIVEIRA JÚNIOR, M.P.; MIRANDA, M.Z.; FAGIOLI, M. Aspectos quantitativos e qualitativos do grão de trigo influenciados por nitrogênio e lâminas de água. Revista Brasileira de Engenharia Agrícola e Ambiental. Campina Grande. v.15, n.5, p.450-457, 2011.

COELHO, E.F.; COSTA, E.L.; LEDO, C.A.S.; SILVA, S.O. Produtividade e eficiência de uso de água das bananeiras 'prata anã' e 'Grand Naine' no terceiro ciclo sob irrigação por microaspersão em tabuleiros costeiros da Bahia. Revista. Brasileira de Fruticultura. Jaboticabal, v.28, n.3, p.435-438. 2006.

COSTA, F.S.; COELHO, E.F.; BORGES, A.L.; PAMPONET, A.J.M.; SILVA, A.A.S.M.; AZEVEDO, N.F. Crescimento, produção e acúmulo de potássio em bananeira 'Galil 18' sob irrigação e fertirrigação potássica. Pesquisa Agropecuária Brasileira, Brasília, v.47, n.3, p.409-416. 2012.

COSTA, S.C.; SOARES, A.A.; SEDIYAMA, G.C.; VIANA, T.V.A.; MOREIRA, F.V.O. Comportamento dos parâmetros indicativos de produção da bananeira 'Pacovan' submetida a diferentes lâminas de irrigação e doses de potássio na Chapada do Apodi-Limoeiro do Norte. Revista Caatinga. Mossoró, v.22, n.4, p.46-52. 2009.

CRISOSTOMO, L.A.; MONTENEGRO, A.A.T.; SOUZA NETO, J.; LIMA, R.N.; Influência da adubação NPK sobre a produção e qualidade dos frutos da bananeira. cv. 'Pacovan'. Revista. 
Ciência. Agronômica. Fortaleza, v.39, m.01, p.4552. 2008 .

EMBRAPA. Manual de métodos de análise de solos. Embrapa Solos. Rio de Janeiro. 2ed. rev. e atual. 1997.212p.

FAO. FAOSTAT. Comércio: bananas. Disponível em: <http://www.appsfao.org > . Acesso em: 21out. 2013.

FERREIRA, D.F. SISVAR - Sistema de análise de variância para dados balanceados. Lavras: UFLA, 1998. 19p.

GANESHAMURTHY, N.; SATISHA, G.; PRAKASH PATIL, P. Potassium Nutrition on yield and quality of fruit crops with special emphasis on banana and grapes. Karnataka Journal of Agricultural Science, Cambridge, v.24, n.1, p.2938, 2011.

HOFFMANN, R.B; OLIVEIRA, F.H.T; SOUZA, A.P; GHEYI, H.R.; SOUZA JÚNIOR, R.F. Acúmulo de matéria seca e de macronutrientes em cultivares de bananeira irrigada. Revista Brasileira de Fruticultura, v.32, p.268-275, 2010.

LEONEL, S.; DAMATTO JÚNIOR, E.R. Caracterização das áreas de cultivo da bananeira 'Maçã' na região de Ribeiro do Sul/SP. Ciência e Agrotecnologia. Lavras, v.31, n.4, p.958-965. 2007.

LORENA, D.R. Produtividade e qualidade de bananas das cultivares 'Grand Naine' e 'BRS Tropical' em função de irrigação e adubação na região do Distrito Federal. 2015. 118f. Dissertação (Mestrado em Agronomia) - Universidade de Brasília, Brasília, 2015.

MARTINS, A.N.; TEIXEIRA, L.A.J.; SEGUINO, E.; HASHIMOTO, J.M.; NARITA, N. Irrigação e adubação potássica via fertirrigação em bananeira 'Willians' - produção e qualidade de frutos. Revista Brasileira de Fruticultura, Jaboticabal, volume especial, E. p.743-751. 2011.

OLIVEIRA JÚNIOR, M.P.; SILVA, C.L.; OLEIVEIRA, C.A.S. Rendimento físico e econômico da aveia preta no Distrito Federal. Revista. Brasileira de Saúde e Produção Animal,
Salvador, v.11, n.1, p.14-24, 2010.

RAMOS, D. P.; LEONEL, S.; MISCHAN, M. M.; DAMATTO JÚNIOR, E.R. Avaliação de genótipos de bananeira em Botucatu - SP. Revista Brasileira de Fruticultura, Jaboticabal, v.31, n.4, p.10921101. 2009.

ROBINSON, J.C.; GALÁN SAÚCO, V. Bananas and plantains. Crop production science in horticulture series, 19. 2 ed. Oxford: CAB Internacional. 2010. 311p.

SANTOS, V.P.; FERNANDES, P.D.; MELO, A.S.; SOBRAL, L.F.; BRITO, M.E.B.; DANTAS, J.D.M.; BONFIM, L.V. Fertirrigação da bananeira cv. Prata-Anã com N e K em um Argissolo Vermelho-Amarelo. Revista Brasileira de Fruticultura, Jaboticabal, v.31, p.567-573. 2009.

SILVA, S.O; SANTOS-SEREJO, J.A.; CORDEIRO, Z.J.M. Variedades. In: BORGES, A.L.; SOUZA, L.S. (ed.). O cultivo da bananeira. Embrapa Mandioca e Fruticultura. Cruz das Almas, BA. 2004. p.45-58.

SOARES, F.A.L.; GHEYI, H.R.; OLIVEIRA, F.H.T.; FERNANDES, P.D.; ALVES, A.N.; SILVA, F.V. Acúmulo, exportação e restituição de nutrientes pelas bananeiras "Prata Anã" e "Grand Naine”. Ciência Rural, Santa Maria, v.38, n.7, p.2054-2058, 2008.

TEIXEIRA, L.A.J.; NATALE, W.; MARTINS, A.L.M. Nitrogênio e Potássio via fertilização e adubação convencional. Estado nutricional das bananas e produção de frutos. Revista Brasileira de Fruticultura. Jaboticabal, v.29, n.1, p.153-160. 2008.

VOSSELEN, V.A.; VERPLANCKE, H.; RANST, V.E. Assessing water consumption of banana: Traditional versus modelling approach. Agricultural Water Management, v.74, p.201$218,2005$.

WEBER, O.B.; MONTENEGRO, A. A.T; SILVA, I.M.N.; SOARES, J. Adubação nitrogenada e potássica em bananeira 'Pacovan' (Musa AAB, subgrupo Prata) na chapada do Apodi, estado do Ceará. Revista Brasileira de Fruticultura, Jaboticabal, v.28, n.1, p.154-157.2006. 